\title{
KAJIAN KONSENTRASI INOKULUM RAGI TERHADAP SIFAT KIMIA DAN BAKTERI ASAM LAKTAT TEMPE KACANG GUDE (Cajanus cajan, L) \\ (Studi on Chemical Properties Yeast Inoculum Concentration and Lactid Acid Bacteria of Pigeonpea Tempeh)
}

\author{
Suparno $^{1)}$, Kusumadati, W. ${ }^{1)}$, Giyanto ${ }^{1)}$, Winerungan, S.A.J. ${ }^{1)}$ \\ 1) Jurusan Budidaya Pertanian Fakultas Pertanian UPR \\ Jl. Yos Sudarso Komplek Tunjung Nyaho Palangka Raya 73111 Kalimantan Tengah \\ Telp.081449186265 Email : suparno.pth@gmail.com
}

Diterima : 19/03/2018 Disetujui : 05/05/2018

\begin{abstract}
Generally, tempeh is made from soybean, but low production of soybean in Indonesia bringing on government have to import its. Soybean import $70 \%$ approximated from United State constitute transgenic soybean which apprehensived have negative effect for health. Indonesia has so many local legume such as pigeon pea (Cajanus cajan (L.) Millsp.). That could be used as soy bean substitute as raw material of tempeh. This study aimed to determine the effect of inoculum concentration pigeonpea beans right to quality and chemical properties of lactid acid bacteria tempeh produced during the fermentation proces. It can be concluded that the inoculum concentration of $2,50 \mathrm{~g} / \mathrm{kg}$ of material, can increase levels of the amino nitrogen of $1,582 \%$, and can inhibit the growth of lactid acid bacteria. It is also recommended for further research conduced on the long soaking, soaking place, and fermentation time is right to improve the quality of pigeonpea beans tempeh produced.
\end{abstract}

Keywords : Concentration of the inoculum, lactid acid bacteria, and tempeh pigeonpea

\begin{abstract}
ABSTRAK
Tempe umumnya berbahan baku kedelai tetapi kurangnya produksi dalam negeri menyebabkan pemerintah harus mengimpornya. Impor kedelai sekitar 70\% yang berasal dari Amerika Serikat merupakan kedelai transgenik yang dikhawatirkan memiliki efek negatif. Indonesia memiliki banyak kacang-kacangan lokal seperti kacang gude (Cajanus cajan (L.) Millsp.). Kacang ini dapat digunakan sebagai bahan pengganti kedelai sebagai bahan baku tempe. Penelitian ini bertujuan untuk mengetahui pengaruh tingkat konsentrasi inokulum kacang gude yang tepat terhadap kualitas sifat kimia dan bakteri asam laktat tempe yang dihasilkan selama proses fermentasi. Hasil penelitian dapat disimpulkan bahwa konsentrasi inokulum 2,50 g/kg bahan, dapat meningkatkan kadar nitrogen amino sebesar $1,582 \%$, dan dapat menghambat pertumbuhan bakteri asam laktat. Disarankan juga untuk diadakan penelitian lebih lanjut mengenai lama perendaman, tempat perendaman, dan waktu fermentasi yang tepat untuk meningkatkan kualitas tempe kacang gude yang dihasilkan.
\end{abstract}

Kata kunci : Konsentrasi inokulum, bakteri asam laktat, dan tempe kacang gude

\section{PENDAHULUAN}

Salah satu bentuk pengolahan dari kacang-kacangan yang tidak asing lagi adalah menjadi produk tempe. Bentuk ini cukup disenangi dan memasyarakat di Indonesia. Tempe memiliki manfaat kesehatan yaitu berpotensi untuk melawan radikal bebas 
sehingga dapat menghambat proses penuaan dan mencegah terjadinya penyakit degeneratif seperti ; aterosklerosis, jantung koroner, diabetes melitus, kanker, dan lain-lain, (Adam, 2015), karena adanya aktivitas enzim superoksida dismutase. Nilai gizi yang unggul lainnya dalam tempe antara lain antioksidan faktor II (6,7,4-trihidroksi isoflavon) yang memiliki sifat antioksidan paling kuat dibandingkan dengan isoflavon dalam kedelai, vitamin $\mathrm{B}_{12}$ yang aktivitasnya semakin meningkat selama proses fermentasi serta kandungan asam glutamat sebagai asam amino esensial yang tinggi. Tempe adalah makanan hasil fermentasi yang dibuat dari kedelai diinokulasi dengan jamur Rhizopus oligosporus dalam fermentasi padat (Dereu, et al., 1994 dalam Kustyawati, 2009). Tempe merupakan salah satu makanan tradisional rakyat Indonesia yang telah dibuat sejak berabad yang lalu tanpa pengetahuan tentang kimia dan mikrobiologi modern. Tempe sangat tahan terhadap pembentukan peroksida, sehingga tidak mudah menjadi tengik, hal ini menunjukkan adanya antioksidan alami seperti tokoferol, lesitin, dan fosfatida yang dikandung tempe (Georgy et al., 1964 dalam Winarno, 2002), Berdasarkan bahan baku yang digunakan, terdapat bermacam-macam tempe seperti tempe kedelai, gembus, kecipir, lupin, kacang tunggak, kacang merah, koro, dan kacang gude.

Impor kedelai Indonesia sekitar $70 \%$ berasal dari Amerika Serikat yang menguasai $60 \%$ pasar kedelai dunia. Kedelai yang berasal dari Amerika Serikat adalah kedelai transgenik. Kelebihan kedelai transgenik antara lain tahan terhadap hama, tahan terhadap herbisida dan kualitas hasil yang tinggi tetapi dikhawatirkan memiliki efek negatif antara lain dapat terjadi perubahan nutrisi, menyebabkan efek alergi atau toksisitas karena proses rekayasa genetika (Gsianturi, 2002).

Upaya untuk mengatasi kekurangan kedelai selain dengan impor kedelai juga dilakukan dengan cara intensifikasi kedelai di beberapa daerah pelaksana Intensifikasi Khusus (Insus), ekstensifikasi pada tanah sawah berpengairan, tadah hujan dan lahan kering dan dengan cara seleksi galur kedelai toleran kekeringan. Adanya kekurangan kebutuhan kedelai tersebut maka perlu dicari alternatif kedelai sebagai bahan baku pembuatan tempe yang memiliki kandungan gizi hampir sama dengan kedelai. Kacangkacangan yang berpotensi sebagai pengganti kedelai yaitu kacang gude.

Kacang gude dilaporkan mengandung senyawa antigizi, yaitu senyawa polifenol (tannin) yang menghambat enzim tripsin, kimotripsin,dan amilase (inhibitor tripsin, inhibitor kimotripsin dan inhibitor amilase) yang dapat mengurangi atau menghambat aktivitas amilase dan lipase pada pankreas; serta asam pitat yang merupakan inhibitor penyerapan Fe (Singh dan Diwakar, 1993; Taylor, 2005). Senyawa senyawa ini menyebabkan masalah apabila kacang gude dikonsumsi dalam jumlah besar. Namun, senyawa antigizi kacang gude sudah lebih sedikit dibanding kacang kedelai, kacang polong, serta kacang pada umumnya.

Proses pembuatan tempe kacang gude yang utama adalah perendaman, pengupasan kulit, perebusan, atau pengukusan, dan inokulasi dengan kapang yang umumnya dari genus Rhizopus sp. Inkubasi dilakukan selama satu sampai dua hari pada suhu kamar, sehingga pada akhir fermentasi gude menjadi kompak dan tertutup oleh miselium kapang berwarna putih sedikit keabu-abuan (Sorensen dan Hesseltine, 2007).

Selama proses fermentasi, kapang tempe memproduksi enzim yang bertanggung jawab terhadap pemecahan substrat kacang gude menjadi molekul-molekul yang lebih kecil dan sederhana, sehingga lebih mudah dicerna. Menurut Tranggono et al., 1996, fermentasi kacang gude dapat mengurangi rasa langu tempe dan senyawa anti nutrisi seperti asam pitat dan enzim tripsin yang dikandung gude mentah, sehingga menghasilkan produk yang enak dan bebas dari racun. 
Tempe segar yang baru jadi hanya dapat disimpan satu sampai dua hari pada suhu ruang. Setelah dua hari, tempe akan membusuk dan tidak dapat dikonsumsi dengan baik. Mutu tempe berkaitan erat dengan laru atau inokulum yang digunakan, lama perendaman, dan waktu fermentasi. Inokulum tempe merupakan sejumlah biakan spora kapang tempe yang digunakan sebagai starter untuk menumbuhkan kapang tempe pada biji kedelai (Sarwono, 2008). Beberapa faktor yang perlu diperhatikan selama proses fermentasi adalah oksigen, aerasi, suhu, uap air, dan keaktifan laru (Rahayu, 1990). Suhu optimum inokulasi atau fermentasi adalah 30 $-35{ }^{\circ} \mathrm{C}$, dan $\mathrm{pH}$ substrat cenderung meningkat dari 4,0 menjadi 6,0 (Retiaty, et al., 2012).

Penelitian bertujuan untuk mengetahui pengaruh tingkat konsentrasi inokulum yang tepat terhadap sifat kimia dan bakteri asam laktat pada produk tempe yang dihasilkan selama proses fermentasi kacang gude.

\section{METODE PENELITIAN}

Penelitian ini dilaksanakan selama 4 (tiga) bulan, mulai bulan Mei sampai Agustus 2017 bertempat di Desa Panarung Rejo dan laboratorium Budidaya Pertanian Fakultas Pertanian Universitas Palangka Raya.

Bahan-bahan yang akan digunakan dalam penelitian ini meliputi : bahan dasar kacang gude, inokulum kapang, aquades, indikator pp, formalin $38 \%, \mathrm{NaOH} 0,1 \mathrm{~N}$, $\mathrm{NaCl}$, larutan buffer, dan akuabides.

Alat-alat yang digunakan meliputi panci, kompor, pisau, timbangan analitik, tampah, termometer, $\mathrm{pH}$ meter, waterbath, pipet tetes, pipet ukur, labu ukur, tabung reaksi, beaker glass, kertas saring, aluminium foil, cawan petri, plastik polietilen, erlenmeyer, botol timbang, dan blender.

Rancangan percobaan yang digunakan ialah Rancangan Acak Lengkap (RAL) yang diulang sebanyak 5 kali, dengan konsentrasi inokulum sebagai perlakuan yang terdiri dari 5 taraf : $A_{1}(0,50 \mathrm{~g} / \mathrm{kg}$ bahan $), A_{2}(1,00 \mathrm{~g} / \mathrm{kg}$ bahan ), $\mathrm{A}_{3}(1.50 \mathrm{~g} / \mathrm{kg}$ bahan $), \mathrm{A}_{4}(2,00 \mathrm{~g} / \mathrm{kg}$ bahan ), dan $A_{5}(2,50 \mathrm{~g} / \mathrm{kg}$ bahan).

Analisis data dilakukan dengan menggunakan analisis ragam, bila antara perlakuan menunjukkan berpengaruh nyata atau sangat nyata terhadap peubah yang sedang diamati, baru kemudian dilanjutkan dengan uji BNJ $5 \%$.

Pelaksanaan percobaan meliputi, tahapan pertama kacang gude dibersihkan dari kotoran yang terikut, kemudian dicuci dengan air yang mengalir. Kacang gude yang sudah bersih direbus selama 30 menit (perebusan I), dilanjutkan dengan pengupasan kulit ari. Setelah kacang gude benar-benar bersih dari kulit, kemudian direndam sesuai perlakuan di dalam bak/tong plastik dengan perbandingan satu bagian kacang gude dan tiga bagian air rendaman. Selesai direndam kacang gude direbus lagi (perebusan II) selama 30 menit, kemudian ditiriskan atau dikering anginkan dan dibantu dengan kipas angin. Baru kemudian kacang gude diinokulasi yaitu dengan mencampur bubuk inokulum dan tepung beras $1,0 \%$ dari berat kacang gude, kemudian gude diaduk sampai benar-benar merata. Banyaknya inokulum yang digunakan dalam proses pembuatan tempe kacang gude sesuai dengan perlakuan di atas. Setelah inokulum rata kacang gude dibungkus dengan kantong plastik polietilen yang telah dilubangi dengan jarak $1 \mathrm{~cm}$ kemudian difermentasi pada suhu kamar.

Data pengamatan diperoleh dari hasil analisis : $\mathrm{pH}$ tempe, asam lemak bebas, kadar nitrogen amino, dan bakteri asam laktat.

\section{HASIL DAN PEMBAHASAN}

\section{pH Tempe}

Perubahan nilai $\mathrm{pH}$ tempe sangat dipengaruhi oleh aktivitas kapang selama proses fermentasi berlangsung. Nilai $\mathrm{pH}$ tempe yang dianalisis berkisar 4,68 - 6,54. Berdasarkan analisis ragam terdapat perbedaan nyata $\mathrm{pH}$ tempe terhadap konsentrasi inokulum. Hal ini berarti konsentrasi inokulum berpengaruh terhadap 
aktivitas kapang selama fermentasi kacang gude berlangsung.

Nilai $\mathrm{pH}$ tempe lebih tinggi dari nilai pH air rendaman, ini disebabkan karena terurainya protein menjadi senyawa - senyawa yang lebih sederhana seperti peptide, peptone, dan asam-asam amino oleh aktifitas enzim proteolitik kapang Rhizopus oligosporus selama fermentasi. Tingkat konsentrasi inokulum menunjukkan perbedaan nyata antar perlakuan. Melalui uji nilai tengah BNJ $5 \%$ didapatkan perlakuan dengan konsentrasi inokulum 2,50 $\mathrm{g} \mathrm{kg}^{-1}$ bahan $\left(\mathrm{A}_{5}\right)$ mempunyai nilai rata - rata $\mathrm{pH}$ tertinggi 7,56, perlakuan ini berbeda nyata dengan perlakuan $1,50 \mathrm{~g} \mathrm{~kg}^{-1}$ bahan $\left(\mathrm{A}_{3}\right), 1,00 \mathrm{~g} / \mathrm{kg}$ bahan $\left(\mathrm{A}_{2}\right)$, dan $0,50 \mathrm{~g}$ $\mathrm{kg}^{-1}$ bahan $\left(\mathrm{A}_{1}\right)$, seperti terlihat pada Gambar 1 .

Pada konsentrasi inokulum yang lebih tinggi terdapat kecenderungan meningkatnya nilai $\mathrm{pH}$ tempe. Hal ini disebabkan pada konsentrasi inokulum yang tinggi jumlah kapang yang tumbuh pada substrat kacang gude lebih banyak, sehingga pemecahan protein menjadi asam amino juga lebih banyak dan hal ini akan meningkatkan nilai $\mathrm{pH}$ tempe.

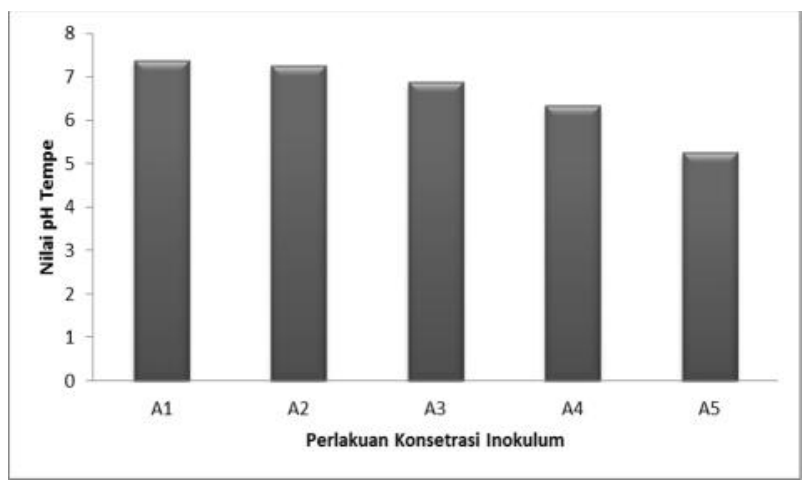

Gambar 1. Perubahan nilai $\mathrm{pH}$ tempe gude pada konsentrasi inokulum yang berbeda

Menurut Shurtleff dan Aoyagi (1979) dalam Mahrita \& Suparno (2009), peningkatan nitrogen terlarut akan menaikkan $\mathrm{pH}$ dari keadaan awal 5,0 sampai mencapai maksimum 7,6 dan selama pertumbuhan kapang tercepat nilai $\mathrm{pH}$ berubah dari 6,0 sampai 6,7. Tempe dikatakan bermutu baik jika pH berkisar antara 6,3 sampai 6,5.

Untuk menjamin pertumbuhan kapang Rhizopus sp. dalam keadaan optimum diperlukan zat gizi dalam jumlah yang cukup, $\mathrm{pH}$ agak netral serta unsur karbon sebagai sumber energi dan nitrogen untuk pengaturan pertumbuhan kapang seperti senyawa karbohidrat, lemak dan protein terpenuhinya dari kacang gude.

\section{Kadar asam lemak bebas}

Kadar asam lemak bebas tempe pada perlakuan konsentrasi inokulum menunjukkan adanya perbedaan nyata. Berdasarkan uji BNJ 5\% pada Tabel 1. menunjukkan bahwa kandungan asam lemak bebas yang tertinggi adalah pada perlakuan konsentrasi inokulum $0.50 \mathrm{~g} \mathrm{~kg}^{-1}$ bahan $\left(\mathrm{A}_{1}\right)$, sedangkan yang terendah pada perlakuan $2,50 \mathrm{~g} \mathrm{~kg}^{-1}$ bahan $\left(\mathrm{A}_{5}\right)$. Hal ini disebabkan karena kecepatan hidrolisa lemak pada konsentrasi inokulum 2,50g $\mathrm{kg}^{-1}$ bahan lebih rendah jika dibandingkan dengan perlakuan lainnya.

Tabel 1. Rata - rata kadar asam lemak bebas dan nitrogen amino pada tempe gude pada perlakuan konsentrasi inokulum

\begin{tabular}{ccc}
\hline $\begin{array}{c}\text { Perlakuan } \\
\text { Konsentrasi } \\
\text { Inokulum } \\
\left(\mathrm{g} \mathrm{kg}^{-1} \text { Bahan }\right)\end{array}$ & $\begin{array}{c}\text { Kadar } \\
\text { Asam } \\
\text { Lemak } \\
\text { Bebas }\end{array}$ & $\begin{array}{c}\text { Kadar } \\
\text { nitogen } \\
\text { amino }(\%)\end{array}$ \\
\hline $0,50\left(\mathrm{~A}_{1}\right)$ & $7,294 \mathrm{a}$ & $1,343 \mathrm{a}$ \\
$1,00\left(\mathrm{~A}_{2}\right)$ & $6,197 \mathrm{~b}$ & $1,432 \mathrm{ab}$ \\
$1,50\left(\mathrm{~A}_{3}\right)$ & $5,195 \mathrm{ab}$ & $1,452 \mathrm{~b}$ \\
$2,00\left(\mathrm{~A}_{4}\right)$ & $5,012 \mathrm{~b}$ & $1,493 \mathrm{~b}$ \\
$2,50\left(\mathrm{~A}_{5}\right)$ & $4,843 \mathrm{~b}$ & $1,582 \mathrm{~b}$ \\
\hline BNJ 5\% & 0,049 & 0,723 \\
\hline
\end{tabular}

Keterangan : Angka-angka yang diikuti huruf yang sama tidak berbeda nyata pada uji BNJ taraf $5 \%$

Terjadinya peningkatan asam lemak bebas pada tempe kacang gude selama proses fermentasi diduga disebabkan oleh adanya penguraian terhadap lemak oleh enzim lipase, 
sehingga terjadi pelepasan asam lemak dari trigliseridanya. Nadia (2006) menyatakan bahwa hidrolisis asam lemak akan terjadi dengan adanya air dan aktivitas kerja enzim lipase.

Steinkraus (1983) menyatakan bahwa enzim lipase juga dapat mengkatalisir reaksi esterifikasi asam lemak bebas dengan gliserol untuk membentuk gliserol baru. Kemudian gliserol akan diubah menjadi gliseroldehid fosfat dan mengikuti jalur glikolisis sehingga terbentuk piruvat sedangkan asam lemak akan diuraikan menjadi molekul-molekul dengan 2 atom $\mathrm{C}$ dan diubah menjadi asetil koenzim $\mathrm{A}$ (Muchtadi, 1989 dalam Deliani, 2012). Hal ini dapat terjadi karena adanya penghambatan terhadap kerja enzim lipase dalam proses hidrolisa lemak. Peningkatan jumlah asam lemak bebas merupakan tanda dari adanya proses kerusakan dari bahan pangan.

\section{Kadar nitrogen amino}

Perlakuan konsentrasi inokulum berpengaruh nyata terhadap kadar nitrogen amino tempe kacang gude, yaitu berkisar antara $1,343 \%$ pada perlakuan $\mathrm{A}_{1}\left(0,50 \mathrm{~g} \mathrm{~kg}^{-1}\right.$ bahan) sampai dengan $1,582 \%$ pada perlakuan $\mathrm{A}_{5}\left(2,50 \mathrm{~g} \mathrm{~kg}^{-1}\right.$ bahan). Semakin tinggi kosentrasi inokulum, kadar nitrogen amino tempe akan semakin tinggi pula. Hal ini diduga berkaitan dengan jumlah kapang yang tumbuh akan lebih banyak pada konsentrasi inokulum yang lebih tinggi, menyebabkan protein kacang gude yang ada akan lebih banyak terurai oleh aktivitas proteolitik kapang tempe menjadi asam - asam amino yang dapat meningkatkan nitrogen amino tempe. Nilai rata - rata perlakuan konsentrasi inokulum terhadap parameter nitrogen amino tempe disajikan pada Tabel $1 \mathrm{di}$ atas.

Menurut Nout and Kiers, (2008), adanya aktivitas proteolitik kapang dapat menyebabkan terhidrolisisnya protein kacang gude membentuk asam - asam amino yang lebih mudah dicerna selama fermentasi gude. Ditambahkan oleh Leon (2009), bahwa proses hidrolisis protein menjadi pepton, peptide, dan asam amino disebabkan oleh aktivitas mikroorganisme dan enzim protease.

Daya cerna protein adalah sebagai kemampuan suatu protein untuk dihidrolisa menjadi asam - asam amino oleh enzim enzim pencernaan. Suatu protein yang mudah dicerna berarti jumlah asam - asam amino yang diserap dan digunakan oleh tubuh relatif tinggi. Sebaliknya, suatu protein yang sukar dicerna berarti jumlah asam - asam amino yang dapat diserap dan digunakan oleh tubuh relatif rendah (Nout and Kiers, 2008). Asamasam amino mengalami katabolisme membentuk amoniak. Adanya pembentukan amoniak akan menaikkan pH karena amoniak memberikan reaksi basa (Lehninger, 1972).

\section{Jumlah Bakteri Asam Laktat}

Adanya perbedaan konsentrasi inokulum pada pembuatan tempe, ternyata dapat mempengaruhi pertumbuhan bakteri asam laktat pada tempe gude yang dihasilkan. Jumlah bakteri asam laktat dari tempe yang dianalisis berkisar antara $6,23 \times 10^{8} \mathrm{sel} \mathrm{g}^{-1}$ sampai dengan $8,39 \times 10^{8}$ sel $\mathrm{g}^{-1}$ tempe. Jumlah bakteri asam laktat dari masing masing perlakuan konsentrasi inokulum pada tempe gude dapat dilihat pada Gambar 2.

Dari hasil analisis ragam ternyata jumlah bakteri asam laktat tempe pada perlakuan konsentrasi inokulum tidak menunjukkan adanya perbedaan nyata.

Adanya bakteri asam laktat pada tempe disebabkan oleh kontaminasi dari air, udara, wadah dan inokulum yang digunakan pada waktu pemeraman. Bakteri asam laktat yang tumbuh pada waktu perendaman kacang gude akan mati akibat proses perebusan, hal ini menurut Bergey, (1974) karena bakteri ini tidak membentuk spora dan kebanyakan bakteri

ini berbentuk bulat. Hal ini didukung pula oleh pendapat Nout and Kiers (2008), bakteri atau kapang pada fermentasi tempe kacang gude dipengaruhi oleh $\mathrm{pH}$, dan kadar nutrisi substrat, serta lamanya fermentasi. 
Pertumbuhan bakteri asam laktat pada tempe, terutama bakteri Streptococcus lactis, Enterobacillus, Lactobacillus sp, Bacillus sp, dan Pediococcus cerevisiae ternyata dapat mencegah pertumbuhan dan produksi enterotoksin dari bakteri Staphylococcus aureus (Andayani et al., 2008).

Retiaty, et al, 2012), menyatakan bahwa asam laktat yang dihasilkan akan menyempurnakan proses fermentasi dengan menghambat terbentuknya amonia bebas yang mengganggu pertumbuhan kapang. Jika jumlah produksi asam tersebut terlalu berlebihan menyebabkan tempe kurang disukai karena adanya bau asam. Menurut Liu and Chin (2013), bakteri asam laktat juga banyak digunakan dalam pembuatan susu fermentasi, bakteri ini dapat memproduksi etanol dan komponen-komponen pembentuk flavour sehingga menghasilkan cita rasa yang spesifik. Selama fermentasi kemungkinan kapang mempunyai peran dalam meningkatkan kualitas nutrisi dan cita rasa tempe (Boutrou, et al., 2015; Kustyawati, 2009).

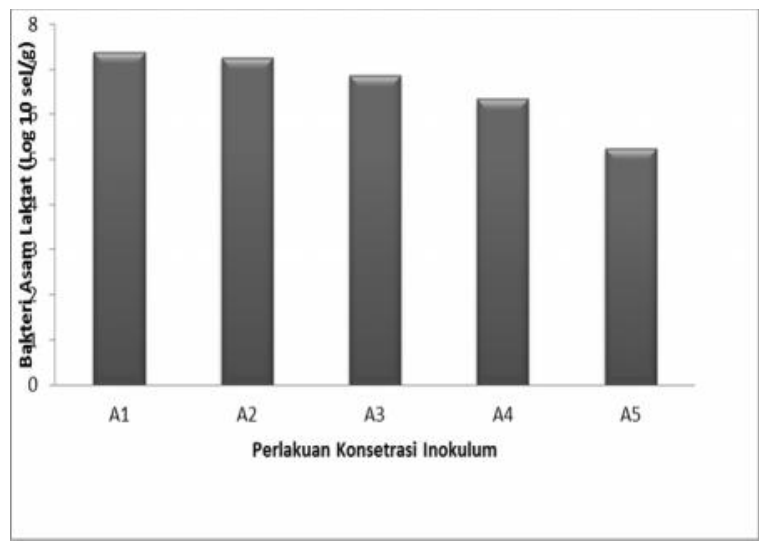

Gambar 2. Perubahan jumlah bakteri asam laktat tempe gude pada konsentrasi inoculum yang berbeda

Sunarto, (1989) menyatakan bahwa pada saat perendaman kedelai, air rendaman didominasi oleh bakteri dari famili Enterobactericeae, Lactobacillus sp dan bakteri asam laktat yang dapat mengurangi kandungan rafinosa 62 persen dan stakiosa 49 persen. Kapang Rhizopus sp. memerlukan jumlah oksigen, kelembaban, air dan panas yang optimum untuk pertumbuhannya, juga dipengaruhi oleh $\mathrm{pH}$ dan kandungan gizi substrat (Retiaty, et al., 2012).

\section{KESIMPULAN}

Konsentrasi inokulum memberikan pengaruh nyata terhadap $\mathrm{pH}$ tempe, kadar asam lemak bebas, dan kadar nitrogen amino, tetapi tidak berpengaruh nyata terhadap jumlah bakteri asam laktat.

Konsentrasi inokulum $2,50 \mathrm{~g} \mathrm{~kg}^{-1}$ bahan merupakan perlakuan terbaik karena dapat meningkatkan nitrogen amino sebesar 1,582\% tempe kacang gude.

Dianjurkan dalam pembuatan tempe kacang gude hendaknya menggunakan inokulum atau ragi yang benar-benar murni dengan viabilitas benih yang masih tinggi serta menggunakan konsentrasi inokulum 2,50 $\mathrm{g} \mathrm{kg}^{-1}$ bahan. Juga perlu dikaji lebih lanjut tentang lama perendaman kacang gude, tempat perendaman dan waktu fermentasi yang tepat.

\section{DAFTAR PUSTAKA}

Adam. 2015. Tempe dan Proses

Pembuatannya. http://www.ad4msan.com//. Diakses pada Senin, tanggal 12 Maret 2017.

Andayani, P., Agustin K.W., and Erni S.M., 2008. Isolation and identification of microorganism in Brown Sorghum tempeh and its potency for degrading starch and protein. Teknologi Pertanian (9) : $95-105$.

Boutrou, R., Kerriou, 1, and Gassi, J.Y., 2015. Contribution of Geotrichum candidum to the proteolysis of soft cheese. International Dairy (24) : 171 -178.

Bergey, D.H., 1974 . Bergey's Manual of Determinative Bacteriology. Williams and Wilkins, Company Baltimore Maryland. 487 p. 
Deliani, 2012. Pengaruh lama fermentasi terhadap kadar protein, lemak, komposisi asam lemak, dan asam fitat pada pembuatan tempe. Tesis. Sekolah Pasca Sarjana Universitas Sumatera Utara, Medan.

Gsianturi. 2002. Pangan Transgenik. http://www.gizi.net/. Diakses pada tanggal 14 Pebruari 2017.

Hesseltine, C.W., M. Smith, B. Bradle, and K.S. Djien, 1983. Antioksidans isolat from fermented soybean. Nature, 202 : $870-882$.

Lehninger, A.L. 1972. Biochemistry. Worth, Publishing Co. Inc., New York.

Leon, S.Y. 2009. Tropikal Food in The Far East. In G.E. Inglett and G. Charalambaous (eds) Chemistry and Nutrition. Volume 2. Academic Press. New York.

Liu, J.R., and W.L. Chin, 2013. Production of kefir from soy milk with or without added glucose, lactose and sucrose. Food Sci 65 (4) : 716 - 719.

Kustyawati, M.E., 2009. Kajian peran yeast dalam pembuatan tempe. Agritech 29(2) : $64-70$.

Mahrita, S., \& Suparno. 2009. Pengaruh Lama Perendaman dan Waktu Fermentasi Terhadap Kadar Amino dan Sifat Organoleptik Tempe Kedelai.Faperta Unpar. Palangka Raya.

Manjik, A.A. dan M. Sumertajaya. 2002. Perancangan Percobaan dengan Aplikasi SAS dan Minitab. Jilid I. IPB Press. Bogor.

Nadia, I., 2006. Kandungan Non Nutrisi dan Bilangan Peroksida Kerupuk Kulit. Universitas Indonesia, Jakarta dalam Journal Matematika, Sains dan Teknologi. LPPM-UT, Vol.7: 111 120.

Nout, M.J.R., dan Kiers, J.L., 2008. Tempeh fermentation, innovation and functionality: update into the third milenium. Applied microbiology (98) : $789-805$.
Rahayu, W.D., 1990. Teknologi Fermentasi Umbi-umbian dan Biji-bijian. PAU Pangan dan Gizi, IPB. Bogor.

Retiaty F., N. Kurniawati, dan Komari, 2012. Pengaruh ketebalan substrat pada fermentasi tempe terhadap kadar vitamin $\mathrm{B}_{1}$. Penelitian Gizi Makan : 35 (2) : $182-188$.

Sarwono, B. 2008. Membuat Tempe dan Oncom. Penebar Swadaya. Jakarta.

Singh, Faujdar and B. Diwakar. 1993. Nutritive Value and Uses of Pigeonpea and Groundnut. International Crops Research Institute for the SemiAridTropics. India.

Sorensen, W.G. and Hesseltine, H. 2007. Carbon and nitrogen utilization by Rhizophus oligosporus. Micology (58) : $681-687$.

Steinkraus, K.H., 1983. Handbook of Indegenous Fermented Foods. Manchel Dekker Inc. New York. 356 p.

Sunarto, A., 1989. Mempelajari Pengaruh Macam Media Pertumbuhan dan Tingkat Konsentrasai Inokulum Terhadap Kualitas Tempe Kedelai : Kajian dari Aspek Mikrobiologis. Skripsi. Jurusan Teknologi Pertanian Faperta Unibraw. Malang.

Taylor, Leslie. 2005. Tropical Plant

Database: GUANDU (Cajanus cajan).www.rain-tree.com/guandu.htm. Diakses pada Senin, 14 Juni 2012

Tranggano, Sutardi, dan Bambang Kuswijayanto. 1996. Aktivitas Tripsin Inhibitor Selama Proses Pembuatan Tempe Kara Benguk (Mucunapruriens), Kacang Tolo (Vigna ungulgulata), dan Gude (Cajanus cajan). Universitas Gajah Mada. Yogyakarta.

Winarno, F. G. 2002. Kimia Pangan dan Gizi. Gramedia Pustaka Utama. Jakarta. 